\title{
Human keratinocyte (HaCaT) stimulation and healing effect of the methanol fraction from the decoction from leaf from Sideroxylon obtusifolium (Roem. \& Schult.) T.D. Penn on experimental burn wound model
}

Tamiris de Fátima Goebel de Souza ${ }^{1}$, Taiana Magalhães Pierdoná ${ }^{1,4}$, Fernanda Soares Macedo $^{1}$, Pedro Everson Alexandre de Aquino ${ }^{1}$, Gisele de Fátima Pinheiro Rangel ${ }^{1}$, Rebeca Silva Duarte ${ }^{1}$, Glauce Socorro de Barros Viana ${ }^{1}$, Ana Paula Negreiros Nunes Alves ${ }^{2}$, Raquel Carvalho Montenegro $^{1}$, Diego Veras Wilke ${ }^{1}$, Edilberto Rocha Silveira ${ }^{3}$, Nylane Maria Nunes de Alencar $^{1 *}$.

1 Universidade Federal do Ceará, Centro de Ciências da Saúde, Departamento de Fisiologia e Farmacologia. CEP: 60430275 - Fortaleza, CE, Brasil.

2 Universidade Federal do Ceará, Centro de Ciências da Saúde, Departamento de Clínica Odontológica. CEP: 60430350 - Fortaleza, CE, Brasil.

3 Universidade Federal do Ceará, Departamento de Química Orgânica e Inorgânica. Campus do Pici, bloco 942, CEP: 60541970 - Fortaleza, CE, Brasil.

4 Faculty of Kinesiology and Recreation Management, Children's Hospital Research Institute of Manitoba (CHRIM), University of Manitoba, Winnipeg, Manitoba, Canada.

*Correspondence: Alencar, NMN. Departamento de Fisiologia e Farmacologia, Centro de Ciências da Saúde, Universidade Federal do Ceará, Fortaleza, CE - Brasil, Tel/Fax: +55-85-33668339/+55-85-988984835, E-mail: nylane@gmail.com. 


\begin{abstract}
The larger number of plants, with therapeutic potential, popularly used in Northeastern Brazil is due to their easy access and the great Brazilian biodiversity. Previously, was demonstrated that the methanol fraction from Sideroxylon obtusifolium (MFSOL) promoted an anti-inflammatory and healing activity in excisional wounds. Thus, this work aimed to investigate the healing effects of MFSOL on human keratinocytes cells (HaCaT) and experimental burn model injuries. HaCaT cells were used to investigate migration and proliferation of cell rates. Female Swiss mice were subjected to seconddegree superficial burn protocol and divided into four treatment groups: Vehicle (cream-base), $1.0 \%$ Silver Sulfadiazine (Sulfa), and $0.5 \%$ or $1.0 \%$ MFSOL cream (CrMFSOL). Samples were collected for quantification of the inflammatory mediators and histological analyses after 3, 7 and 14 days on evaluation. As result, MFSOL (50 $\mu \mathrm{g} / \mathrm{ml})$ stimulated $\mathrm{HaCaT}$ cells by increasing proliferation and migration rates. Moreover, CrMFSOL $0.5 \%$ attenuated myeloperoxidase (MPO) activity and also stimulated the release of IL-1 $\beta$ and IL-10, after 3 days with treatment. CrMFSOL $0.5 \%$ enhanced wound contraction, promoted tissue remodeling improvement and highest collagen production after 7 days, and VEGF release after 14 days. Therefore, MFSOL evidenced the stimulation of human keratinocyte (HaCaT) cells and improvements on wound healing via inflammatory modulation on burn injuries.
\end{abstract}

Keywords: Sideroxylon obtusifolium (Roem. \& Schult.). Methanol fraction. Human keratinocyte. Wound healing. Burn wounds. 


\section{INTRODUCTION}

The reconstruction of the epidermal barrier rupture through re-epithelialization is essential to reduce a wound infection risk and recover the normal skin function (Rousselle, Braye, \& Dayan, 2018). The burn healing process is affected by interaction among cells and molecules, including growth factors, cytokines, and chemokines. Initially, the inflammatory response occurs to prevent the invasion of pathogens and the activation of fundamental signals. It is also followed by the proliferative phase, when fibroblasts and keratinocytes will restore the tissue damage through collagen synthesis, epithelialization, angiogenesis, and production of extracellular matrix (Horst, Chouhan, Moiemen, \& Grover, 2018; Markeson et al., 2015).

The use of medicinal plants in Brazil is still common because of both high costs of traditional medicines and easy access to medicinal plants which are sold on flea markets of large and small cities (Macedo et al., 2018). Sideroxylon obtusifolium (Roem. \& Schult.) T.D. Penn is a native tree in Central and South America. It is characteristic of the Brazilian semiarid region (Caatinga), where is known as "quixaba", due to its round blackberries when ripened. This medicinal plant species is widely known and used in folk medicine in the cities of Northeast of Brazil, where dry parts of quixaba, leaves or trunk bark, are sold in local markets due to their anti-inflammatory and healing properties (Oliveira et al., 2012).

The risk of extinction of the species, by the predatory extractive procedures of its bark, directed the attention of scientific studies to other plant parts like the leaves. Two studies with the hydroalcoholic fractions obtained from leaves of S. obtusifolium showed antifungal activity against Candida albicans (Pereira et al., 2016; Sampaio et al., 2017). Other study demonstrated antinociceptive and anti-inflammatory properties of L-proline, $\mathrm{N}$-methyl-(2S, 4R)-trans-4-hydroxy-L-proline (NMP), presents in major proportion in the methanol fraction of leaves of S. obtusifolium (MFSOL) (Aquino et al., 2017). Also, NMP showed wound healing activity on excisional wounds, which was related to its anti-inflammatory and antioxidant actions (Aquino et al., 2019). However, there is no knowledge of whether methanol fraction MFSOL is the healing process in wounds caused by burns. Then, this study aimed to investigate the effect of MFSOL on human keratinocytes (HaCaT) in vitro and on surface burn model in mice. 


\section{EXPERIMENTAL}

\subsection{Plant material}

Leaves of S. obtusifolium (Sapotaceae) were collected from specimens growing in Mauriti city, state of Ceará, Brazil. A voucher specimen (sample no. 10.648) was taxonomically validated by Dr. Maria Arlene Pessoa da Silva, at the "Herbario Caririense Dárdano de Andrade Lima”, in Regional University of Cariri, Ceará, Brazil.

The methanol fraction from S. obtusifolium leaves (MFSOL) was obtained according to the procedure previously described, to obtain a yellowish amorphous powder (Aquino et al., 2017). The MFSOL was dissolved in sterile water and treated to cell cultures at final concentrations of $6.25-100 \mu \mathrm{g} / \mathrm{ml}$.

\subsection{Cell Culture}

Immortalized human keratinocyte cells (HaCaT, CLS Cell Lines Service) were provided by Dr. Raquel Carvalho Montenegro, Pharmacogenetics Laboratory of the Drug Research and Development Center - NPDM, Federal University of Ceará. Cells were grown in Dulbecco's modified Eagle's medium (DMEM, Gibco®), supplemented with $1.0 \%$ antibiotics (100 U/ml penicillin and $100 \mu \mathrm{g} / \mathrm{ml}$ streptomycin, Gibcoß) and 10\% fetal bovine serum (FBS, Gibco®), at $37^{\circ} \mathrm{C}$ in $5 \% \mathrm{CO}_{2}$ atmosphere in a humidified incubator. The cells were maintained in exponential growth through periodic maintenance.

\subsection{Cytotoxicity assays}

The principle of MTT assay is based on the mitochondrial cell viability to reduce, by the succinate-tetrazole reductase enzyme system, the yellow tetrazolium salt (MTT) to a salt-formazan, which is purple in color (Mosmann, 1983). After 24, 48 and $72 \mathrm{~h}$ of incubation with MFSOL, cells received $20 \mu \mathrm{L}$ of 3-(4,5-dimethylthiazolyl)-2,5diphenyltetrazolium bromide (MTT) $(5 \mathrm{mg} / \mathrm{ml})$ and were incubated at $37{ }^{\circ} \mathrm{C}$ for $3 \mathrm{~h}$. Then, the medium was removed and $150 \mu \mathrm{L}$ of dimethyl sulphoxide (DMSO) was added and the plate was homogenized for $5 \mathrm{~min}$. The absorbance was determined by a microplate reader (Elisa Asys Expert Plus) at a wavelength of $540 \mathrm{~nm}$.

The sulphorhodamine B (SRB) assay was used to evaluate cell viability, based on the measurement of cellular protein content. HaCaT cells $\left(2 \times 10^{4}\right.$ cells $\left./ \mathrm{ml}\right)$ were plated in 
96 multiwell plates and after $24 \mathrm{~h}$ treated with MFSOL $(6.25-100 \mu \mathrm{g} / \mathrm{ml})$. After the 24 , 48 and $72 \mathrm{~h}$ of treatment, the cells were fixed with $10 \%$ trichloroacetic acid and incubated with SRB solution $(0.4 \%)$ for $30 \mathrm{~min}$. The dye excess was removed by washing repeatedly with $1 \%$ acetic acid. The protein-bound dye was dissolved in 10 $\mathrm{mM}$ Tris-base solution and the optical density was determined at $570 \mathrm{~nm}$ using a Microplate Autoreader (Multiskan FC - Thermo Scientific) (Houghton et al., 2007). The results were expressed as a percentage of cell viability.

\subsection{Scratch wound healing assay}

The scratch wound healing assay was performed to determine the effects of MFSOL on the proliferation and migration of human keratinocytes. These cells were dispersed in DMEM with $10 \%$ FBS $\left(5 \times 10^{4}\right.$ cells $\left./ \mathrm{ml}\right)$ and incubated with $5 \% \mathrm{CO}_{2}$ at $37{ }^{\circ} \mathrm{C}$ in a 24 well plate. When the cells formed a confluent monolayer, they were scratched using a tip vertically with a $200 \mu \mathrm{l}$ of each well. Cellular debris were removed and washed with PBS. Pictures (200x) were taken after 24, 48 and 72 h of incubation with MFSOL (25, 50 and $100 \mu \mathrm{g} / \mathrm{ml}$ ) in $1 \mathrm{ml}$ of fresh medium (Räsänen \& Vaheri, 2010). To evaluate only the migration, an antimitotic agent, mitomycin C $\left(10 \mu \mathrm{g} / \mathrm{ml}\right.$; Sigma $\left.{ }^{\circledR}\right)$ was added for $1 \mathrm{~h}$, following the scratch protocol. Immediately, the cells were treated with MFSOL (25 and $50 \mu \mathrm{g} / \mathrm{ml}$ ) and, after photomicrographs, the migration was evaluated at the initial time, and after 24 and $48 \mathrm{~h}$ of incubation (D. Choi, Piao, Wu, \& Cho, 2013). The open area of the scratch was measured using TSCRATCH® software in each analysis period in the same initial site, the percentage of the open area was measured using the formula: Open area $(\%)=$ Open area time $X \div$ Open area initial time $\times 100$.

\subsection{Animals}

Female Swiss mice ( 8 weeks old) were kept in a light/dark $12 \mathrm{~h}$ cycle, temperature $(23 \pm$ $\left.2^{\circ} \mathrm{C}\right)$ and humidity $(55 \pm 10 \%)$ at Central Animal House of the Federal University of Ceará (UFC). The animals received food (Nuvilab, Quimtia®, Brazil) and water ad libitum. The experimental protocols were performed according to the ethical standards established in the Ethical Principles on Animal Experimentation adopted by the Brazilian National Council for the Control of Animal Experimentation (CONCEA), analyzed and approved $\left(\mathrm{n}^{\circ} 8862290518\right)$ by the Ethics Committee on the Use of Animals of Federal University of Ceará. 


\subsection{Superficial burn model and treatment}

Firstly, the animals were anesthetized with xylazine hydrochloride $(10 \mathrm{mg} / \mathrm{kg}$, i.p.) and ketamine hydrochloride (100 mg/kg, i.p.). After anesthesia, the dorsal surface skin (4 $\mathrm{cm} \times 2 \mathrm{~cm}$ ) was shaved followed by asepsis with $1.0 \%$ iodopovidone followed by $70 \%$ ethanol. A second-degree superficial burn was induced by direct contact of a heated square stainless steel plate $\left(1 \mathrm{~cm}^{2}\right)$ and regulated at $100{ }^{\circ} \mathrm{C}$ for 6 seconds (Lima-Junior et al., 2017). The animals were divided into 4 groups: 1) control vehicle with cream base Lanette (anionic cream); 2) CrMFSOL 0.5\% and 3) CrMFSOL 1.0\%, which fraction was included in the base dermatological cream in two concentrations, respectively; and 4) $1 \%$ silver sulfadiazine with cream base Lanette as the positive control. Immediately after the injury, the treatments were administered once per day for 14 days. After induction of the lesion, the animals received saline solution $0.9 \%$ (s.c.) for fluid replacement and were kept in a warm environment and under observation until complete recovery.

\subsection{Burn wound contraction}

The lesions were measured and photographed on 3, 5, 7, 9, 12 and 14 days after induction of the superficial burn. A digital caliper was used to measure the horizontal (h), and vertical (v) measurements of the burn ( $\mathrm{mm}$ ), and then the area of the lesion was calculated by multiplying the two measurements, $A=h \times v\left(\mathrm{~mm}^{2}\right)$. The rate of contraction of the lesion was calculated by the formula: Contraction $(\%)=($ initial area evaluation area) / (initial area) x 100. After macroscopic wound healing examination ( $n=10$ /group), all mice were euthanized using anesthetic overdose (xylazine and ketamine) and tissues were collected immediately and kept at $-80^{\circ} \mathrm{C}$ for biochemical analyses.

\subsection{Histological and collagen fibers analysis}

The burn injuries were collected after 7 days of burn injury to histological study. Samples were removed and fixed in 10\% formol ( $\mathrm{pH}$ 7.4) for $24 \mathrm{~h}$ ( $\mathrm{n}=6 /$ group). Tissues were submitted to dehydration and impregnated in paraffin. Sections of those fragments were cut to $4 \mu \mathrm{m}$ in thickness and stained with hematoxylin and eosin. Histopathological changes were evaluated with optical microscopy (Olympus BX 51, Japan). The histopathological parameters were determined and scored from 0 to 4 , 
where zero score corresponding: absence of ulcer (AU), remodeled connective tissue (RCT); score 1: AU, fibrosis (F), slight chronic inflammation (CI); score 2: presence of ulcer (PU), F, moderate CI; score 3: PU, chronic inflammation process (granulation tissue) and score 4: PU, acute process (dilated vessels, mixed inflammatory infiltrate with neutrophils) (Adapted from Cavalcante et al., 2011). Stained with picrosirius red (PSR) were performed to measure the collagen fibers in the connective tissue of burn wounds. The Color Deconvolution (RGB) plugin of the Image J® software was used to measure the percentage of collagen area represented by the red image produced concerning the total area of the image (Alves et al., 2015).

\subsection{Myeloperoxidase activity assay}

The myeloperoxidase (MPO) activity was performed in burns biopsies after 3 days of burn injury (Adapted from Faunce et al., 1999). The samples were homogenized using a polytron tissue extractor in phosphate buffer ph 7.4, centrifugated ate $10.000 \mathrm{rpm}$ for 30 min and the pellet obtained here used to determine myeloperoxidase activity by oxidative reaction with 3,3',5,5'-tetramethylbenzidine (TMB; 1,6 mM, Sigma $\left.{ }^{\circledR}\right)$ and oxygen peroxide $\left(\mathrm{H}_{2} \mathrm{O}_{2} ; 0,5 \mathrm{mM}\right)$. The number of neutrophils was quantified from a standard neutrophil curve ( $1 \times 10^{5}$ neutrophils/ well). The absorbance of the samples ( $\mathrm{n}=6$ /group) was quantified in a spectrophotometer at the wavelength of $450 \mathrm{~nm}$, and the results were expressed as the number of neutrophils/mg of tissue (cell/ mg of tissue).

\subsection{Mediators of inflammation and vascular endothelial growth factor measurement}

The biopsies of the burns were performed after 3 days of burn injury to quantify the release of inflammatory mediators TNF- $\alpha$, IL-1 $\beta$, IL-10 and after 14 days of growth factor VEGF (Fujimi et al., 2009). Tissues were triturated and homogenized 10\% (mg tissue $/ \mu \mathrm{L})$ at $4{ }^{\circ} \mathrm{C}$ in $\mathrm{PBS}$ solution $(\mathrm{pH} 7.4)$, and the residues removed after centrifugation at $5000 \mathrm{rpm}$ for $5 \mathrm{~min}$. The protocol was performed according to the manufacturer's recommendation to the conventional sandwich technique (R\&D Systems $\left.{ }^{\circledR}\right)$. After the ELISA protocol, the absorbance of the samples was quantified in a spectrophotometer at the wavelength of $450 \mathrm{~nm}$. The results were expressed as cytokines $/ \mathrm{ml}$ of homogenate, and the concentration of the samples was obtained from a serial dilution of recombinant cytokine standard ( $n=6 /$ group). 


\subsection{Statistical analysis}

Results are presented as the mean \pm standard deviation (SD) for each experimental group. Statistical comparisons of the data were performed by one-way ANOVA followed by Tukey post-test using GraphPad Prism software version 5.0. Differences between groups were considered significant when $p \leq 0.05$.

\section{RESULTS}

\subsection{MFSOL enhanced the cellular viability of human keratinocyte HaCaT}

The proliferative assay evidenced that MFSOL did not show cytotoxicity in human keratinocytes, at any of the incubation periods. MFSOL was able to increase mitochondrial viability (by MTT assay) after 24, 48 and $72 \mathrm{~h}$ at concentrations of 12.5 $50 \mu \mathrm{g} / \mathrm{ml}(\mathrm{p}<0.001)$. The concentration $50 \mu \mathrm{g} / \mathrm{ml}$ of MFSOL stimulated an increase in the viability of $42.8 \%$ (after $24 \mathrm{~h}$ ), $47.5 \%$ (after $48 \mathrm{~h}$ ) and $46.8 \%$ (after $72 \mathrm{~h}$ ) compared to the Control group ( $\mathrm{p}<0.001$ ) (Fig. $1 \mathrm{~A}, 1 \mathrm{~B}$ and $1 \mathrm{C}$, respectively). At the highest concentration $(100 \mu \mathrm{g} / \mathrm{ml})$ it showed an increase of $43.6 \%(\mathrm{p}<0.001)$ only after $24 \mathrm{~h}$. Following, the SRB assay revealed an increase of viable cells, but less expressive than MTT assay. After $24 \mathrm{~h}$ and $48 \mathrm{~h}$, the concentration $100 \mu \mathrm{g} / \mathrm{ml}$ of MFSOL increased $14.5 \%$ and $21 \%$ cell viability of HaCaT cells $(\mathrm{p}<0.001)$, what also was observed with 50 $\mu \mathrm{g} / \mathrm{ml}(8.2 \%$ and $11.21 \% ; \mathrm{p}<0.001)$, respectively. These effects were less pronounced after $72 \mathrm{~h}$ when at 25 and $50 \mu \mathrm{g} / \mathrm{ml}$ of MFSOL showed an increase of $7.1 \%$ and $7.4 \%$ $(\mathrm{p}<0.001)$ of viability.

\subsection{MFSOL stimulates cell proliferation and migration in the HaCaT scratch assay in keratinocytes}

To evaluate the effect of MFSOL on cell proliferation and migration of $\mathrm{HaCaT}$, the in vitro healing assay known as Scratch was used. Through the MTT and SRB assays, concentrations of 25,50 and $100 \mu \mathrm{g} / \mathrm{ml}$ were selected to perform Scratch. After $24 \mathrm{~h}$, the percentage of the open area observed after treatment with $25 \mu \mathrm{g} / \mathrm{ml}(\mathrm{p}<0.05)$ and 50 $\mu \mathrm{g} / \mathrm{ml}(\mathrm{p}<0.001)$ of MFSOL was reduced by $14.5 \%$ and $34 \%$, respectively, compared to the Control (Fig. 2A). This effect was also observed after $48 \mathrm{~h}$ after treatment with $12.5 \%$ (22\%; p<0.05), $25 \mu \mathrm{g} / \mathrm{ml}(28 \% ; \mathrm{p}<0.001)$ and $50 \mu \mathrm{g} / \mathrm{ml}(38 \% ; \mathrm{p}<0.001)$ of MFSOL, respectively, when compared to Control (Fig. 2B). Finally, after $72 \mathrm{~h}$ of the scratch assay, the open area was reduced by $25 \mu \mathrm{g} / \mathrm{ml}(42.1 \% ; \mathrm{p}<0.05)$ and $50 \mu \mathrm{g} / \mathrm{ml}$ 
(72.6\%) of MFSOL ( $\mathrm{p}<0.001$ ), compared to Control (Fig. 2 C). The effect of MFSOL on $\mathrm{HaCaT}$ was photographed and visualized through rapid panotype staining. It was observed by the higher cell density in $25 \mu \mathrm{g} / \mathrm{ml}$ and $50 \mu \mathrm{g} / \mathrm{ml}$ of MFSOL treatment in comparison to the Control (Fig. 2D). Considering the stimulatory effect of MFSOL on cell proliferation and migration, mitomycin $\mathrm{C}$ was used to inhibit cell duplication and thus enable the isolated evaluation of the effect of MFSOL on cell migration. At the concentration of $50 \mu \mathrm{g} / \mathrm{ml}$ was efficient in stimulating the migration of the cells to the center of the open area by $26 \%$ after $24 \mathrm{~h}(\mathrm{p}<0.05)$ and $67 \%$ after $48 \mathrm{~h}(\mathrm{p}<0.01)$ of incubation, compared to Control (Fig. 2F-G).

\subsection{CrMFSOL reduces the area of superficial burns}

In the superficial burn model, the contraction of lesions was measured for 14 days to monitor the temporal evolution of the area of superficial burns. The contraction rate of the Sham and Vehicle groups was similar in all the periods studied (Figure 3A-F). After 3 days, the treatment with CrMFSOL $1.0 \%$ showed an increase by $123.2 \%(\mathrm{p}<0.05)$ in the contraction of lesions, while, the Sulfa group $(\mathrm{p}<0.05)$ also presented similar effect (110.7\%), compared to the Vehicle group (Fig. 3A). Following after 5 days (Fig. 3B) and 7 days (Fig. 3C), CrMFSOL 0.5\% (p<0.01; p<0.05), CrMFSOL 1.0\% ( $<<0.05$; $\mathrm{p}<0.01)$ and Sulfa $(\mathrm{p}<0.01 ; \mathrm{p}<0.01)$ groups showed an increase of lesions contraction, respectively, compared to the Vehicle group (Fig. 3C). At 9 days, only CrMFSOL 0.5\% group increased $(26 \%)$ the lesions contraction $(\mathrm{p}<0,05)$ when compared to Vehicle (Fig. 3D). Near the closure of lesion, after 12 and 14 days of analysis, all the groups presented no differences between them (Fig. 3E and 3F). The photographs represent the evolution during the cicatricial process of the studied times 3rd (A), 5th (B), 7th (C), 9th (D), 12th (E) and 14th (F) day (Fig. 3G), respectively.

\subsection{CrMFSOL promotes tissue remodeling improvement, reepithelialization and collagen deposition on superficial burns}

Histopathological analysis of samples of superficial burns in mice showed that after seven days the Sham and Vehicle groups had ulcer, granulation tissue and presence of acute inflammatory infiltrate (Fig. 4A and 4B). On the other hand, Sulfa, CrMFSOL $0.5 \%$, and $1.0 \%(\mathrm{p}<0.05)$ groups stimulated the appearance of a thin epithelium covering the ulcer, with the presence of a corneal layer protecting the newly formed epithelium. There was still the transition from acute to chronic inflammatory infiltrate 
and the development of a remodeling connective tissue (Fig. 4C, 4D and 4E, respectively). To determine the total collagen deposition in the tissue, the staining of picrosirius red was used after 7 days of treatment. The Vehicle and Sham groups had a similar percentage of total collagen. While Sulfa, CrMFSOL $0.5 \%$ and $1.0 \%$ groups were increased $36 \%, 30.7 \%$ and $48.1 \%$ ( $\mathrm{p}<0.05)$, respectively, the production of collagen in comparison to the Vehicle group (Figure 4F).

\subsection{CrMFSOL on cytokine inflammatory status in superficial burns}

The treatment with $0.5 \%$ CrMFSOL group reduced $32 \%(\mathrm{p}<0.05)$ the activity of the myeloperoxidase (MPO) when compared to the Vehicle group after 3 days of burninduced injury (Fig. 5A). Moreover, the levels of TNF- $\alpha$ were not altered by CrMFSOL $0.5 \%$ or $1.0 \%$ (Fig. 5B). However, CrMFSOL $0.5 \%(\mathrm{p}<0.001)$ and $1.0 \%(\mathrm{p}<0.01)$ CrMFSOL increased IL-1 $\beta$ release ( $112.5 \%$ and $94.4 \%$, respectively) compared to the Vehicle group, what was also observed with the Sulfa group treatment $(\mathrm{p}<0.001)$ (Fig. 5C). Additionally, the release of IL-10, an anti-inflammatory cytokine, was higher in all treated groups compared with the Vehicle group. CrMFSOL $0.5 \%$ treatment showed a considerable increase of $153.7 \%(\mathrm{p}<0.001)$ and $59.8 \%(\mathrm{p}<0.01)$ when compared to the Vehicle and Sulfa groups, respectively (Fig. 5D).

\subsection{CrMFSOL stimulated release of VEGF on superficial burns}

To evaluate the angiogenesis process, the VEGF level was measured after 14 days of induced superficial burn in animals. The treatment with CrMFSOL $0.5 \%$ was able to increase VEGF release by $95.6 \%(\mathrm{p}<0.05)$ compared to the Vehicle group (Fig. 5E).

\section{DISCUSSION}

This work reports, for the first time, the healing activity on burn wounds of methanol fraction from Sideroxylon obtusifolium (MFSOL). Regarding the traditional use of stem bark, this work sheds light on a sustainable exploration of S. obtusifolium by shifting to, the use of its leaves. MFSOL was not cytotoxic and promoted an increase of cellular viability of human keratinocytes ( $\mathrm{HaCaT})$, suggesting an effect on the proliferation of HaCaT. Similarly, the hydroalcoholic extract of the trunk bark of Stryphnodendron adstringens ("barbatimão"), another native species of the Brazilian Caatinga, also increased the viability of HaCaT (Pellenz et al., 2018). In the scratch assay, MFSOL showed a proliferative and migratory effect on keratinocytes during wound healing. In 
this sense, a study with leaves of Aloe vera, Aloe ferox and Aloe marlothii presented rapid coverage rates in the scratch assay on HaCaT keratinocytes and low cellular cytotoxicity (Fox et al., 2017).

To evaluate the isolate effect on cell migration, mitomycin $\mathrm{C}$, an antimitotic agent was used to interfere with cell duplication in the scratch assay. Thus, MFSOL (25 and $50 \mu \mathrm{g} / \mathrm{ml}$ ) stimulated not only proliferation but also the migration of HaCaT. A similar result was observed by the methanol fraction of the extract of Centella asiatica (100 $\mu \mathrm{g} / \mathrm{ml}$ ) that increased the cell migration rate, besides assisting in the remodeling during cicatrization of excisional wounds in rabbits (Azis et al., 2017). Epidermal cell turnover is fundamental for rapid wound healing, in which keratinocytes are stimulated to proliferate by regulating growth factors and intercellular contact (J. H. Choi et al., 2017).

One of the parameters of success in healing is reepithelialization. When keratinocytes fail to recover the epidermal barrier, new openings may occur, especially in chronic lesions (Rousselle et al., 2018). As a pharmacological model, the induction of superficial burn in mice was chosen to evaluate the effect of a topical cream (CrMFSOL) containing MFSOL at concentrations of $0.5 \%$ and $1.0 \%$ for 14 days. The faster evolution of the contraction area on burn wounds, evidenced by treatment with CrMFSOL after 3, 5, 7 and 9 days, did reduce the risk of infections and accelerated the other stages of healing, such as proliferation and remodeling. Its effect was similar to the control group (Silver Sulfadiazine), the standard treatment for the prevention of infections and the promotion of cicatrization in burns (Moser, Pereima, \& Pereima, 2013). A methanol extract of Carissa spinarum (1.0\%) used in the treatment of partial burns in rats also showed a more pronounced effect on the contraction of the lesion in the first days evaluated, at the same concentration that MFSOL (Sanwal \& Chaudhary, 2011).

The topic treatment with CrMFSOL stimulated the early formation of a new epithelium and a remodeling of connective tissue, with a higher collagen deposition after 7 days. Similarly, a phytomodulatory hydrogel with hemicelluloses extracted from seeds of Caesalpinia pulcherrima (Fabaceae) and mixed with phytomodulatory proteins obtained from the latex of Calotropis procera, enhanced the healing effects by high collagen deposition and modulating some aspects of the inflammatory phase (Vasconcelos et al., 2018). Corroborating with this data, it was discovered that the methanol fraction of quixaba leaves (MFSOL), contains as a main component, the 
NMP, a derivative from L-proline (amino acid precursor of collagen), that showed cicatrizant effect in the topical treatment of induced excisional lesions in mice, through modulation of the inflammatory response, and increase of the antioxidant response and stimulation of the production of collagen fibers (Aquino et al., 2019). Also, a study with the ethanol extract of the leaves of Passiflora edulis reproduced an acceleration the repair, to reduce the number of inflammatory cells on the 7th day of treatment and to increase the number of fibroblasts and the deposition and organization of the fibers of collagen in 14 days of repair of burns in mice (Barros, Santos, Coelho, Reis, \& Bezerra, 2016).

The progression of thermal injury damages adjacent capillaries causing ischemia, which activates adhesion of polymorphonuclear cells, such as neutrophils, which release inflammatory mediators as well as the production of reactive oxygen species (ROS) (Parihar, Parihar, Milner, \& Bhat, 2008). While TNF- $\alpha$ release induces the fundamental inflammatory response in damaged tissue, the high level of IL-1 $\beta$ in mouse burns was correlated to the increased activity of epidermal keratinocytes. These cells work to restore the epidermal barrier function when stimulated by nanofibrous of peptides hydrogels, (Loo et al., 2014). A biomembrane containing latex proteins from Calotropis procera increased levels of TNF- $\alpha$ and IL1- $\beta$ in the model of excisional wounds in mice and promoted an improvement in wound healing (Ramos et al., 2016). Also, CrMFSOL $0.5 \%$ treatment provided an increase in IL- $1 \beta$ levels, but it did not influence on TNF- $\alpha$ release on burn injuries. Moreover, CrMFSOL 0.5\% reduced MPO activity, after 3 days of treatment, which may have influenced the transition from acute to chronic inflammatory infiltrate after 7 days earlier than the other treatment with Silver Sulfadiazine.

Besides, IL-1 $\beta$ has been reported to stimulate VEGF expression during inflammation, which consequently stimulates migration and proliferation of endothelial cells by the promotion of angiogenesis. Thus, the healing effect of a polysaccharide extracted from Sanguisorba officinalis to induce epithelization and angiogenesis was related to the increase of VEGF and IL-1 $\beta$ in mouse burn model (Zhang, Chen, \& Cen, 2018). Similarly, CrMFSOL 0.5\% promoted a greater release of VEGF after 14 days of treatment on burn injuries, which may have contributed to a better epithelization and reorganization of the connective tissue.

As an anti-inflammatory factor, IL-10 is also produced by epidermal keratinocytes and is important in the suppression of ROS, Nitric Oxide (NO) and the control of 
proinflammatory cytokines secreted by macrophages (Tharuka et al., 2018). Briefly, the CrMFSOL $0.5 \%$ provided an increase in IL-10 levels, MFSOL was able to modulate the inflammatory response and contribute to recovering of tissue damage promoted by burn injury.

\section{CONCLUSION}

The methanol fraction extracted from the leaves of Sideroxylon obtusifolium demonstrated wound healing potential on stimulating proliferation and migration of human keratinocytes. Also, MFSOL was able to modulate the inflammatory response and improve the tissue repairment of superficial burns in mice. Thus, it is believed that the anti-inflammatory and wound healing potential of MFSOL may provide support for further studies that enable the development of an herbal product indicated to the treatment of wounds and burns.

\section{Conflict of interest}

The authors declare no conflict of interest.

\section{Acknowledgments}

This study was financially supported by CNPq (Conselho Nacional de Desenvolvimento Científico e Tecnológico). We acknowledge the support from Drug Research and Development Center (NPDM) for the pharmacological tests. 


\section{Figures Legends}

Figure 1 - Effect of MFSOL on cell viability of human keratinocytes (HaCaT). An increase of cell viability of keratinocytes was produced by MFSOL $(6.25-100 \mu \mathrm{g} / \mathrm{mL})$ after 24h, 48h, and 72h incubation, by MTT (A, B, and C) and SRB (D, E, and F) methods, respectively. To illustrate the HaCaT density, photographs were taken at 200x magnification after 48 hours of treatment with 25 and $50 \mu \mathrm{g} / \mathrm{ml}$ of MFSOL (G). Values were represented as the mean $\pm \mathrm{SE}$ from at least three independent experiments. ${ }^{*} p<0.05,{ }^{* *} p<0.01$ and ${ }^{* * *} p<0.001$, compared with Vehicle group.

Figure 2 - MFSOL stimulated proliferation and cell migration rates of $\mathrm{HaCaT}$ in the Scratch assay. A scratch was produced in a monolayer of HaCaT cells and photographs were taken, before (0h) and after $24 \mathrm{~h}(\mathrm{~A}), 48 \mathrm{~h}(\mathrm{~B})$ and $72 \mathrm{~h}(\mathrm{C})$ of treatment with MFSOL, with a $200 \times$ magnification (D). As cells double and migrate, space is filled and the open area is reduced. A pre-treatment with mitomycin C $(10 \mu \mathrm{g} / \mathrm{ml})$ was also performed one hour before Scratch to inhibit cell proliferation, allowing only evaluation of cell migration after $24 \mathrm{~h}(\mathrm{E})$ and $48 \mathrm{~h}(\mathrm{~F})$. The wells were photographed (200x) after $24 \mathrm{~h}$ and $48 \mathrm{~h}(\mathrm{G})$. Photomicrographs are produced by the open area analysis (\%) through the TSCRATCH® program. The results were expressed as mean \pm standard error of the mean. One-way ANOVA followed by the Tukey test was used for statistical analysis of the data. ${ }^{*} p<0.05,{ }^{* *} p<0.01$ and ${ }^{* * *} p<0.001$ represent a significant difference compared to the Control group (water).

Figure 3 - Effect of MFSOL on the contraction of induced burns in mice. The percentage of contraction of the burns was expressed after the 3, 5, 7, 9, 12 and 14 days (A, B, C, D, E, and F, respectively). In the initial days, the wound healing of the groups treated with $0.5 \%$ and $1.0 \%$ CrMFSOL was faster. The animals were treated with a single daily application of dermatological creams for 14 days, the CrMFSOL group corresponds to the $0.5 \%$ and $1.0 \%$ of MFSOL, the Sulfa group to the $1 \%$ silver sulfadiazine cream and Vehicle to the base vehicle cream without any addition of active substance. The superficial burns were photographed for macroscopic monitoring on days $3,5,7,9,12$ and 14 after the burn was produced (G). One animal per group was chosen to represent the group according to the results obtained by the contraction of the lesion. One-way ANOVA followed by the Tukey test was used for statistical analysis of the data. ${ }^{*} p<0.05$ and ${ }^{* *} p<0.01$ represents a significant difference compared to the Sham group and ${ }^{\#} p<0.05$ and ${ }^{\# \#} p<0.01$ for the Vehicle group, ( $=10$ animals / group).

Figure 4 - MFSOL promoted tissue remodeling improvement, reepithelialization and stimulated collagen production on superficial burns after 7 days of treatment. Photomicrographs of histological slides (Hematoxylin Eosin stain) from burn lesions on the 7th day after surgery (100x) were represented by Sham (A); Vehicle (B); Silver Sulfadiazine (C), $0.5 \%$ CrDFSO-M (D) and 1.0\% CrDFSO-M (E) groups ( $\mathrm{n}=6$ animals/group). Black arrows indicate the presence of acute inflammatory infiltrate in groups $\mathrm{A}$ and $\mathrm{B}$, while red arrows indicate the presence of atrophic epithelium, presence of a corneal layer and absence of ulcer in groups C, D and E. The lesions were stained 
by the picrosirius red method and photographed in six fields (200x). The percentage of total collagen present on the 7 th day was determined by Image $\mathrm{J}{ }^{\circledR}$ software $(\mathrm{F})$. The results were expressed as the mean of the six areas of each wound per group. One-way ANOVA followed by the Tukey test was used for statistical analysis of the data. ${ }^{*} p$ $<0.05$ corresponds to the difference in relation to the Sham group and ${ }^{*} p<0.05$ in the Vehicle group ( $\mathrm{n}=6$ animals/group/day).

Figure 5 - The treatment with MFSOL reduced myeloperoxidase activity (MPO) and stimulated release of IL-1 $\beta$, IL-10 after 3 days and VEGF after 14 days. The levels of TNF- $\alpha$ were not reduced significantly. The results of MPO (A) were expressed as mean \pm standard error of the mean of cell/mg of tissue, while TNF- $\alpha$ (B), IL-1 $\beta$ (C), IL-10 (D) and VEGF (E) were expressed as the mean \pm standard error of the mean of cytokine $/ \mathrm{ml}$ from supernatant/mg tissue. One-way ANOVA followed by the Tukey test was used for statistical analysis of the data. ${ }^{\#} p<0.05,{ }^{\#} p<0.01$ and ${ }^{\# \#} p<0.001$ represents a significant difference in comparison to Vehicle group. ${ }^{\mathrm{a}} p<0.05$ and ${ }^{\text {aaa }} p<0.001$ in relation to the Sulfa group ( $\mathrm{n}=6$ animals/group/day). 


\section{Figure 1}
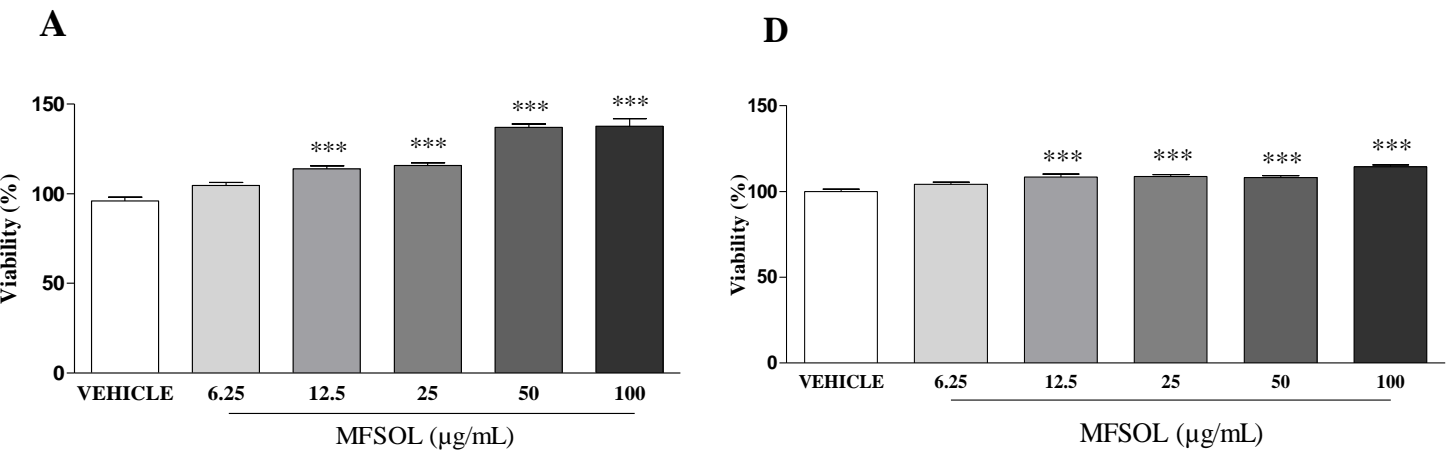

G

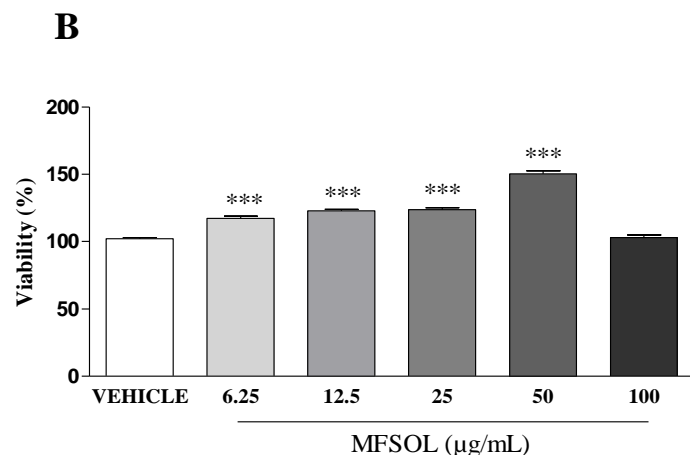

\section{E}
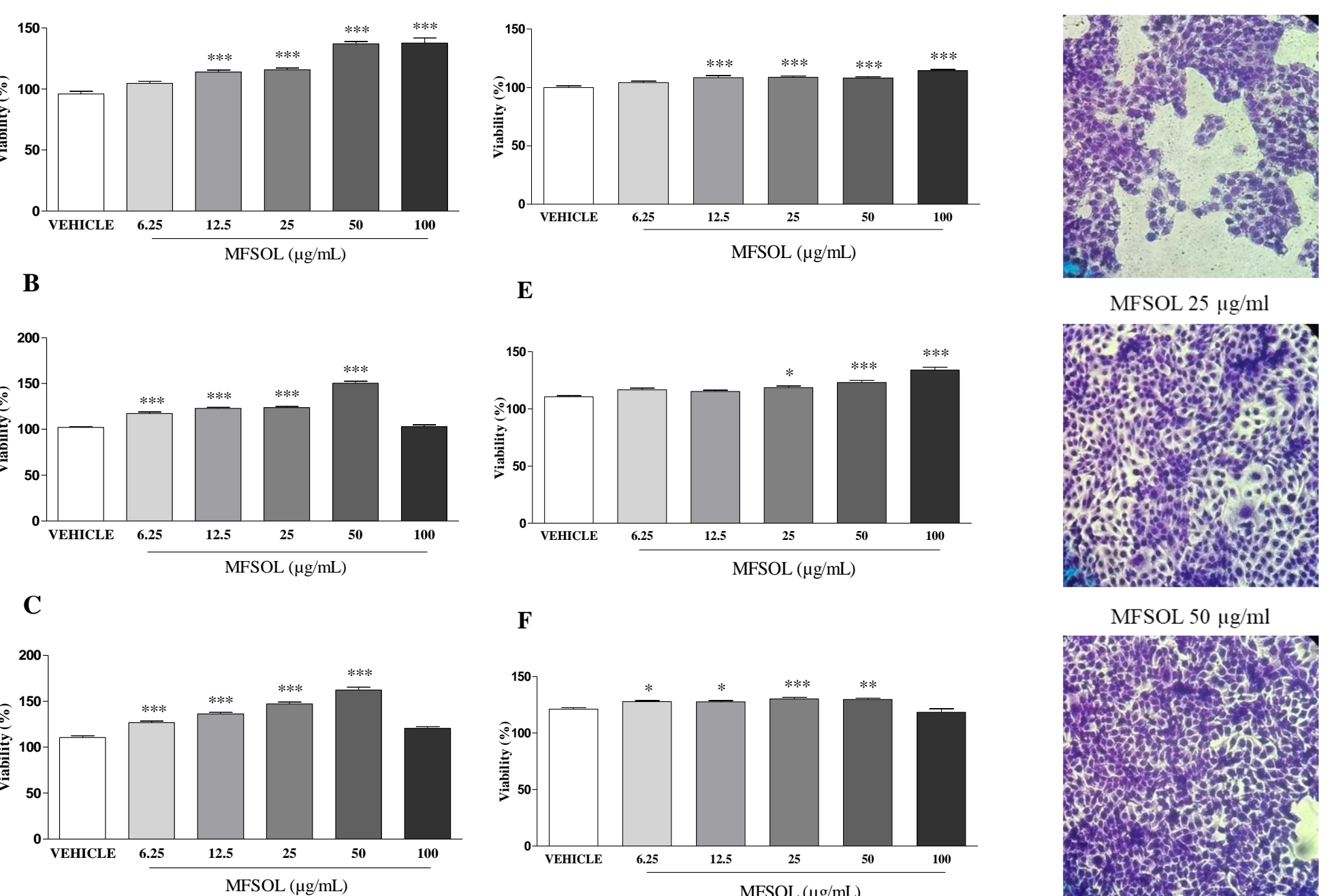

\section{F}

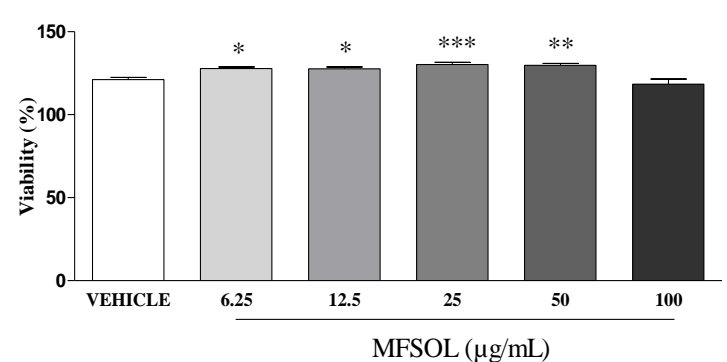

MFSOL $25 \mu \mathrm{g} / \mathrm{ml}$

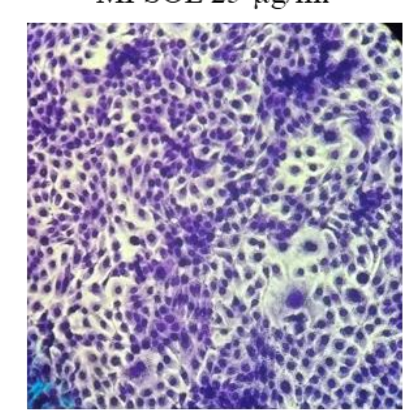

MFSOL $50 \mu \mathrm{g} / \mathrm{ml}$

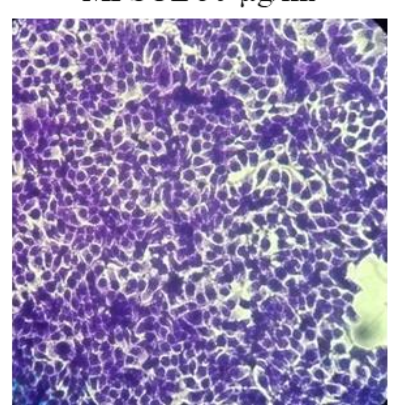




\section{Figure 2}
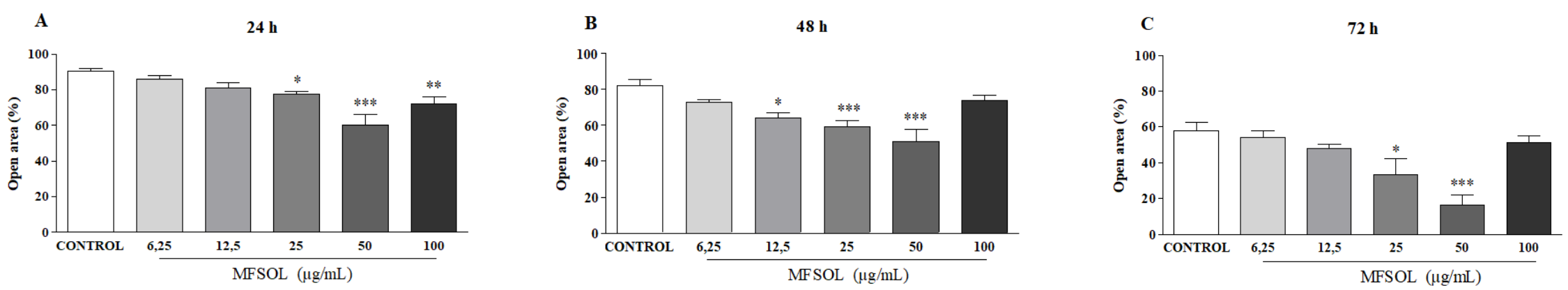

D

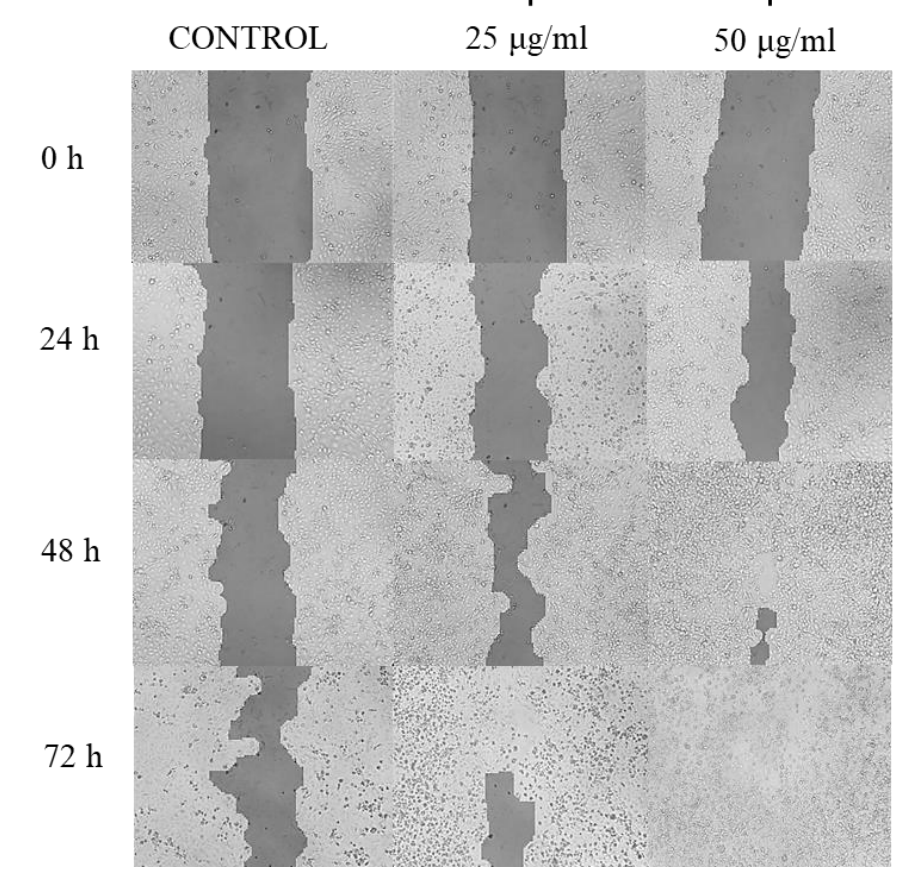

E

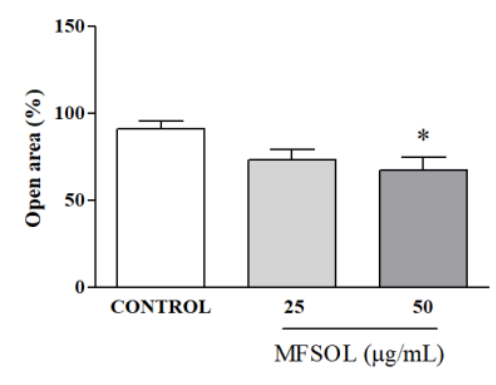

$$
\text { F }
$$

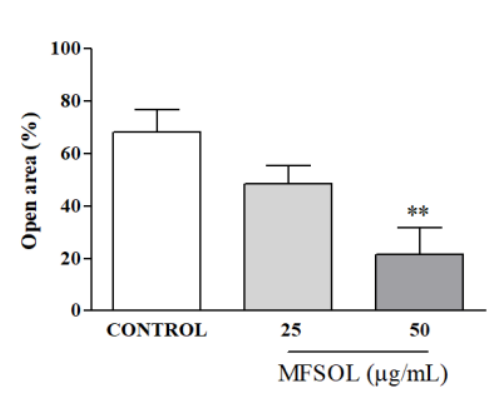

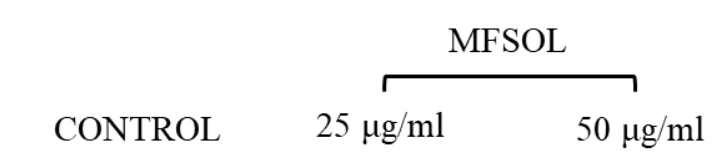

$0 \mathrm{~h}$

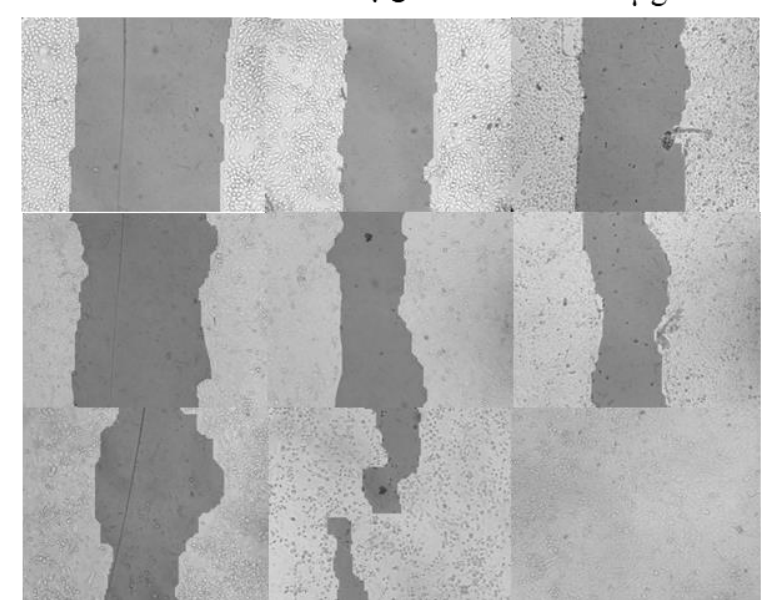


Figure 3
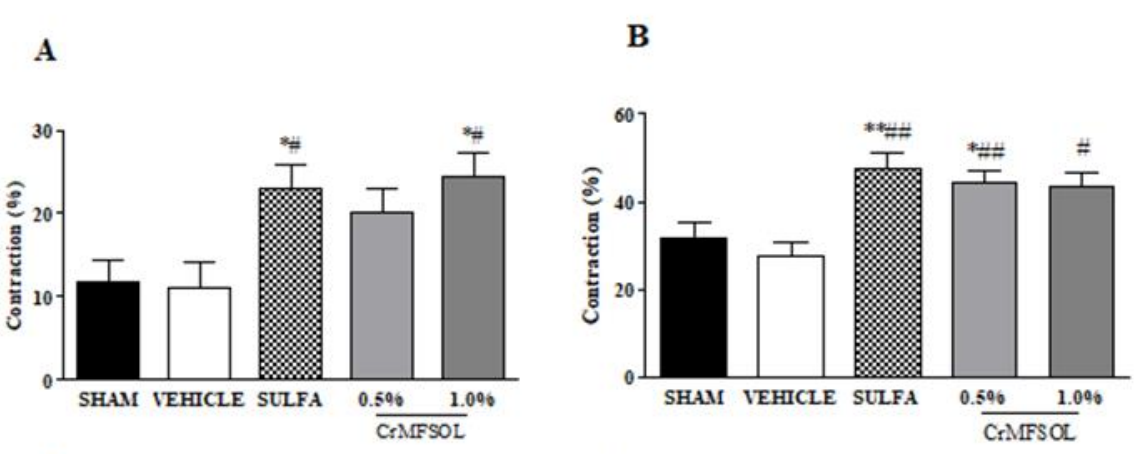

G
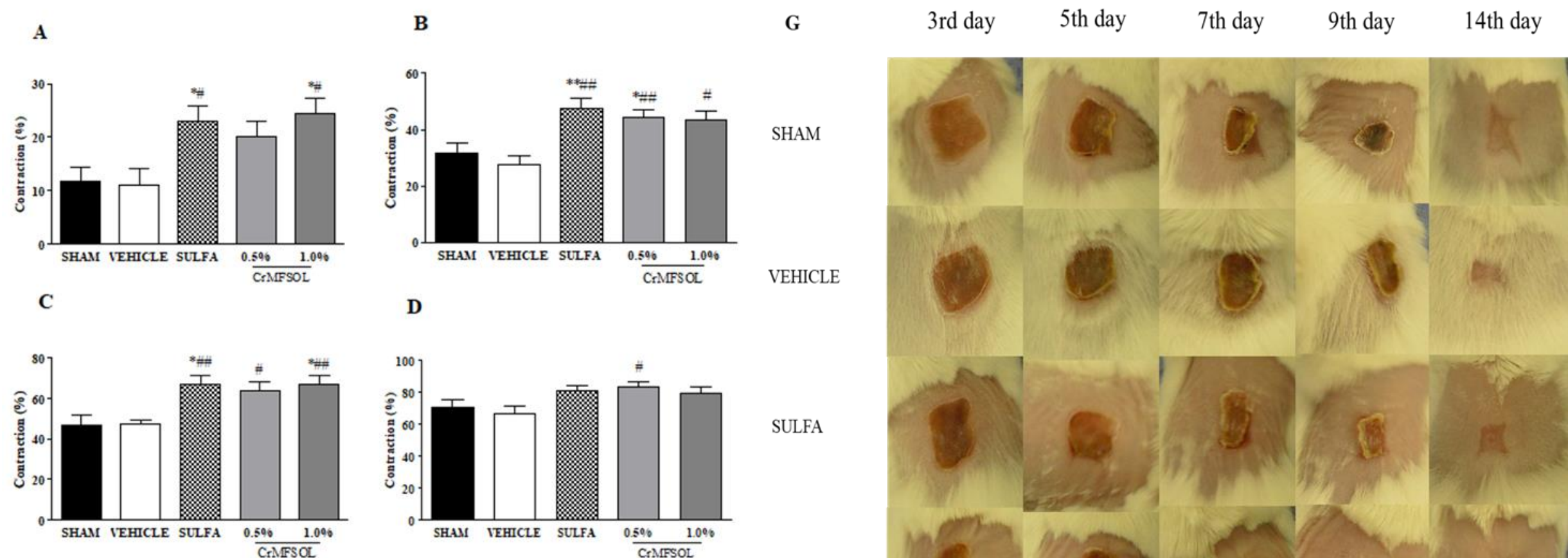

D

SHAM

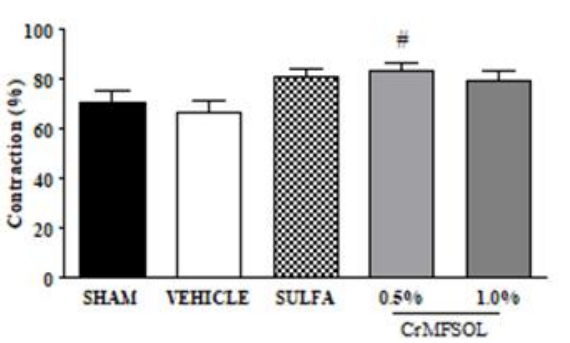

SULFA

E

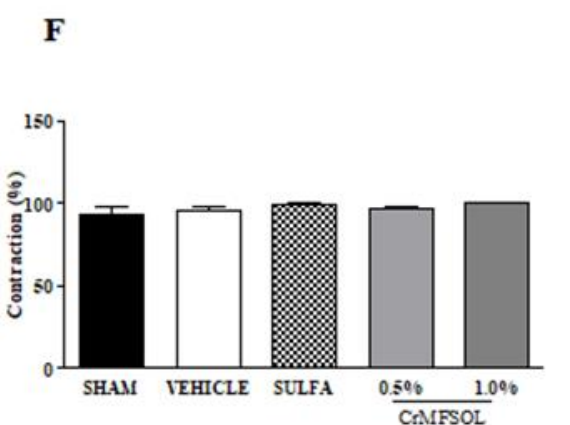

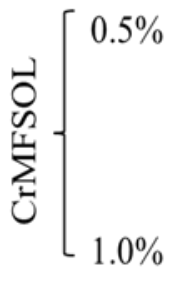

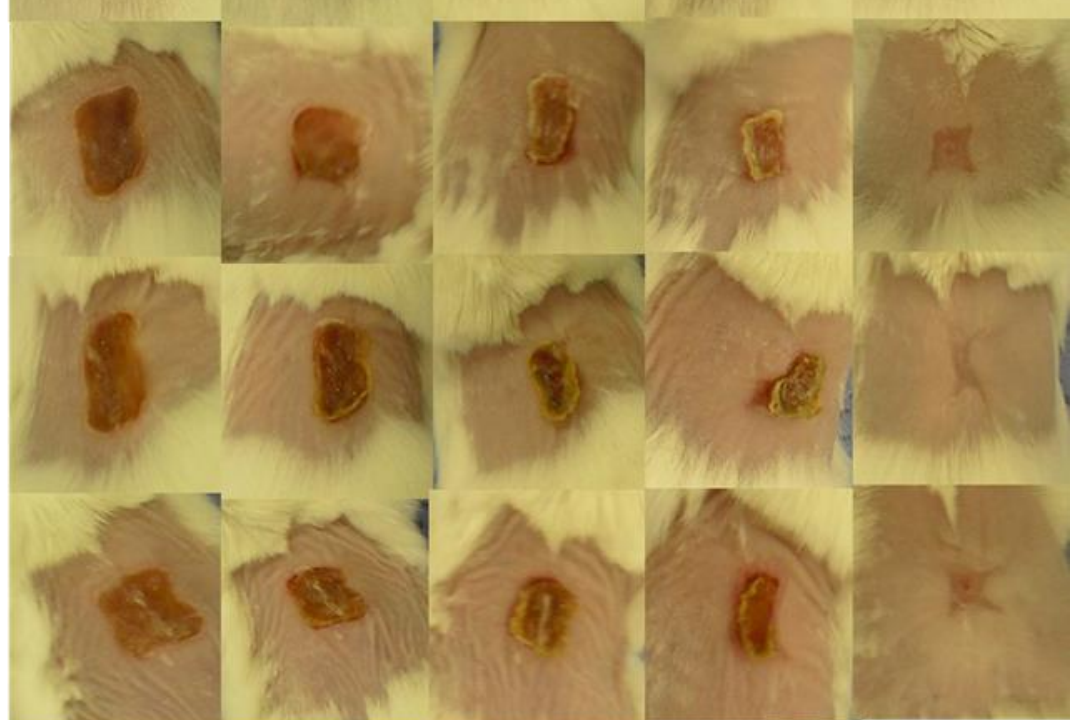




\section{Figure 4}
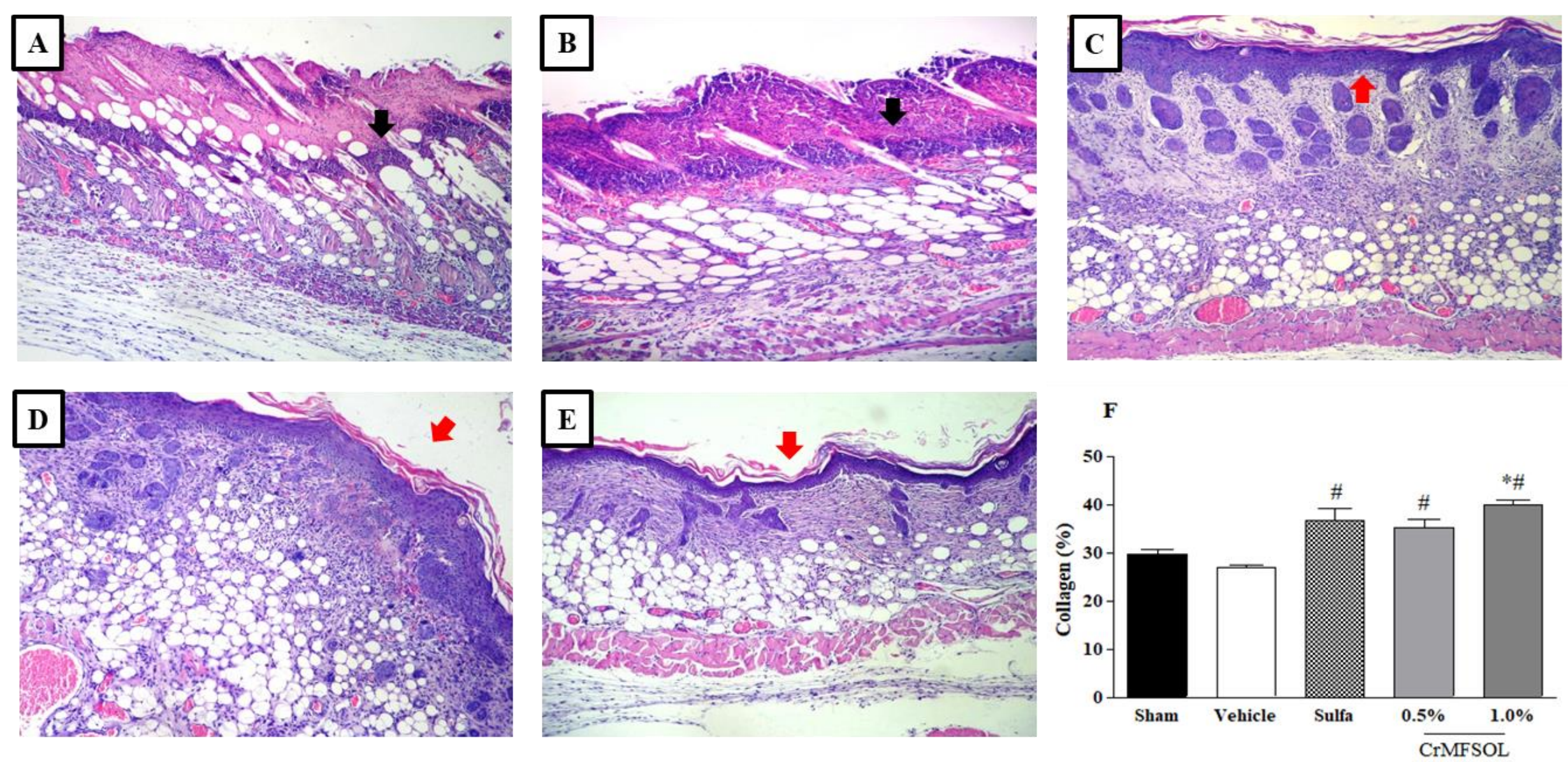


\section{Figure 5}

A

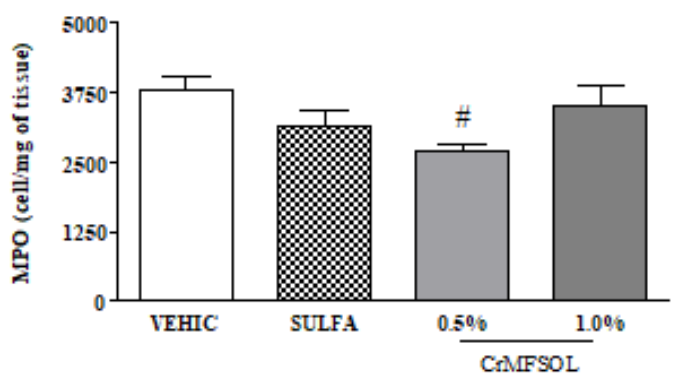

B

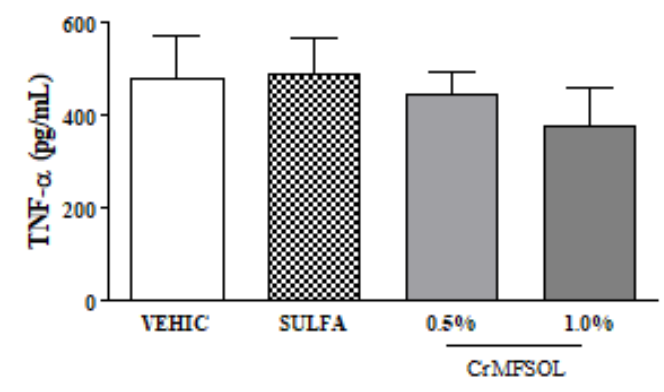

C

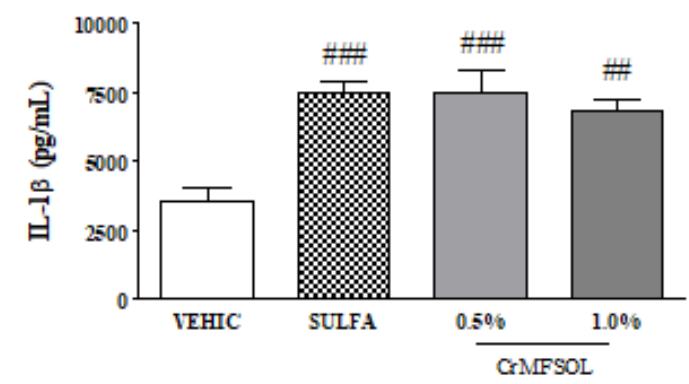

D

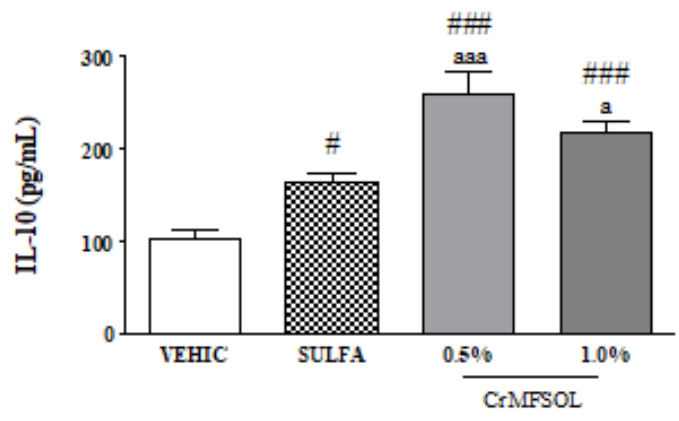

E

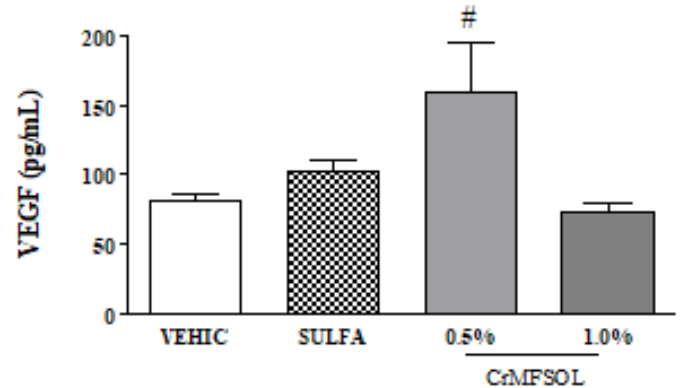




\section{References}

Alves, A. P. N. N., Verde, M. E. Q. L., Júnior, A. E. C. F., Silva, P. G. B., Feitosa, V. P., Júnior, E. M. L., Miranda, M. J. B., \& Filho, M. O. M. (2015). Avaliação microscópica, estudo histoquímico e análise de propriedades tensiométricas da pele de tilápia do Nilo. Rev Bras Queimaduras, 14(3), 203-210.

Aquino, P. E. A., Magalhães, T. R., Nicolau, L. A. D., Leal, L. K. A. M., Aquino, N. C., Santos, S. M., Neves, K. R. T., Silveira, E. S., \& Viana, G. S. B. (2017). The antiinflammatory effects of N-methyl-(2S,4R)-trans-4-hydroxy-L-proline from Syderoxylon obtusifolium are related to its inhibition of TNF-alpha and inflammatory enzymes. Phytomedicine, 24, 14-23. https://doi.org/10.1016/j.phymed.2016.11.010

Aquino, P. E. A., Souza, T. F. G., Santos, F. A., Viana, A. F. S. C., Louchard, B. O., Leal, L. K. A. M., Rocha, T. M., Evangelista, J. S. A. M., Aquino, N. C., Alencar, N. M. N., Silveira, E. R., \& Viana, G. S. B. (2019). The Wound Healing Property of $\mathrm{N}$-Methyl- (2S, 4R) - trans -4-Hydroxy-L-Proline from Sideroxylon obtusifolium is Related to its Anti-Inflammatory and Antioxidant Actions. Journal of Evidence-Based Integrative Medicine, 24, 1-11. https://doi.org/10.1177/2515690X19865166

Azis, H. A., Taher, M., Ahmed, A. S., Sulaiman, W. M. A. W., Susanti, D., Chowdhury, S. R., \& Zakaria, Z. A. (2017). In vitro and In vivo wound healing studies of methanolic fraction of Centella asiatica extract. South African Journal of Botany, 108, 163-174. https://doi.org/10.1016/j.sajb.2016.10.022

Barros, E. M. L., Santos, D. K. B., Coelho, N. P. M. F., Reis, M. R., \& Bezerra, B. G. (2016). Efeitos da Passiflora edulis S. no processo de cicatrização em queimaduras induzidas em camundongos. ConScientiae Saúde, 15(1), 122-128. https://doi.org/10.5585/ConsSaude.v15n1.5783

Cavalcante, G. M., Paula, R. J. S., Souza, L. P., Sousa, F. B., Mota, M. R. L., \& Alves, A.P.N.N. (2011). Experimental model of traumatic ulcer in the cheek mucosa of rats. Acta Cirurgica Brasileira, 26(3), 227-234. https://doi.org/10.1590/S010286502011000300012

Choi, D., Piao, Y. L., Wu, Y., \& Cho, H. (2013). Control of the intracellular levels of prostaglandin E2 through inhibition of the 15-hydroxyprostaglandin dehydrogenase for wound healing. Bioorganic and Medicinal Chemistry, 21, 
4477-4484. https://doi.org/10.1016/j.bmc.2013.05.049

Choi, J. H., Song, Y. S., Song, K., Lee, H. J., Hong, J. W., \& Kim, G. C. (2017). Skin renewal activity of non- thermal plasma through the activation of $\beta$-catenin in keratinocytes. Scientific Reports, 5, 1-11. https://doi.org/10.1038/s41598-01706661-7

Faunce, D. E., Llanas, J. N., Patel, P. J., Gregory, M. S., Du, L. A., \& Kovacs, E. J. (1999). Neutrophil chemokine production in the skin following scald injury. Burns, 25, 403-410.

Fox, L. T., Mazumder, A., Dwivedi, A., Gerber, M., du Plessis, J., \& Hamman, J. H. (2017). In vitro wound healing and cytotoxic activity of the gel and whole-leaf materials from selected aloe species. Journal of Ethnopharmacology, 200(January), 1-7. https://doi.org/10.1016/j.jep.2017.02.017

Fujimi, S., Lapchak, P. H., Zang, Y., Macconmara, M. P., Maung, A. A., Delisle, A. J., Mannick, J. A., \& Lederer, J. A. (2009). Murine dendritic cell antigen-presenting cell function is not altered by burn injury. Journal of Leukocyte Biology, 85, 863870. https://doi.org/10.1189/jlb.0408257

Horst, T. B., Chouhan, G., Moiemen, N. S., \& Grover, L.M. (2018). Advances in keratinocyte delivery in burn wound care. Advanced Drug Delivery Reviews, 123, 18-32. https://doi.org/10.1016/j.addr.2017.06.012

Houghton, P., Fang, R., Techatanawat, I., Steventon, G., Hylands, P. J., \& Lee, C. C. (2007). The sulphorhodamine (SRB) assay and other approaches to testing plant extracts and derived compounds for activities related to reputed anticancer activity. Methods, 42(4), 377-387. https://doi.org/10.1016/j.ymeth.2007.01.003

Lima-Junior, E. M., Picollo, N. S., Miranda, M. J. B. de, Ribeiro, W. L. C., Alves, A. P. N. N., Ferreira, G. E., Parente, E. A., \& Moraes-Filho, M. O. (2017). Uso da pele de tilápia (Oreochromis niloticus), como curativo biológico oclusivo, no tratamento de queimaduras. Rev Bras Queimaduras., 16(1), 10-17.

Loo, Y., Wong, Y., Cai, E. Z., Ang, C., Raju, A., Lakshmanan, A., Koh, A. G., Zhou, H. J., Lim, T., Moochhala, S. M., \& Hauser, C. A. E. (2014). Ultrashort peptide nanofibrous hydrogels for the acceleration of healing of burn wounds. Biomaterials, $35(17)$, 4805-4814. https://doi.org/10.1016/j.biomaterials.2014.02.047

Macedo, J. G. F., Menezes, I. R. A., Ribeiro, D. A., Santos, M. O., Mâcedo, D. G., Macêdo, M. J. F., Almeida, B. V., Oliveira, L. G. S., Leite, C. P., \& Souza, M. M. 
A. (2018). Analysis of the Variability of Therapeutic Indications of Medicinal Species in the Northeast of Brazil: Comparative Study. Evidence-Based Complementary and Alternative Medicine, 2018, 1-28. https://doi.org/10.1155/2018/6769193

Markeson, D., Pleat, J. M., Sharpe, J. R., Harris, A. L., Seifalian, A. M., \& Watt, S. M. (2015). Scarring, stem cells, scaffolds and skin repair. Journal Of Tissue Engineering And Regenerative Medicine, 9, 649-668. https://doi.org/10.1002/term.1841

Moser, H., Pereima, R. R., \& Pereima, M. J. L. (2013). Evolução dos curativos de prata no tratamento de queimaduras de espessura parcial. Rev Bras Queimaduras, 12(2), $60-67$.

Mosmann, T. (1983). Rapid Colorimetric Assay for Cellular Growth and Survival: Application to Proliferation and Cytotoxicity Assays. Journal of Immunological Methods, 65, 55-63. https://doi.org/10.1016/0022-1759(83)90303-4

Oliveira, A. P., Raith, M., Kuster, R. M., Rocha, L. M., Hamburguer, M., \& Potterat, O. (2012). Metabolite Profiling of the Leaves of the Brazilian Folk Medicine Sideroxylon obtusifolium. Planta Medica, 78, 703-710. https://doi.org/10.1055/s0031-1298269

Parihar, A., Parihar, M. S., Milner, S., \& Bhat, S. (2008). Oxidative stress and antioxidative mobilization in burn injury. Burns, 34, 6-17. https://doi.org/10.1016/j.burns.2007.04.009

Pellenz, N. L., Barbisan, F., Azzolin, V. F., Duarte, T., Bolignon, A., Mastella, M. H., Teixeira, C. F., Ribeiro, E. E., Cruz, I. B. M., \& Duarte, M. M. M. F. (2018). Analysis of In Vitro Cyto- and Genotoxicity of Barbatimão Extract on Human Keratinocytes and Fibroblasts. BioMed Research International, 2018, 1-11. https://doi.org/10.1155/2018/1942451

Pereira, J. V., Freires, I. A., Castilho, A. R., Cunha, M. G., Alves, H. S., \& Rosalen, P. L. (2016). Antifungal potential of Sideroxylon obtusifolium and Syzygium cumini and their mode of action against Candida albicans. Pharmaceutical Biology, 54(10), 2312-2319. https://doi.org/10.3109/13880209.2016.1155629

Ramos, M. V., Alencar, N. M. N., Oliveira, R. S. B., Freitas, L. B. N., Aragão, K. S., Andrade, T. A. M., Frade, M. A. C., Brito, G. A. C., \& Figueiredo, I. S. T. (2016). Wound healing modulation by a latex protein-containing polyvinyl alcohol biomembrane. Naunyn-Schmiedeberg's Archives of Pharmacology, 389, 747-756. 
https://doi.org/10.1007/s00210-016-1238-2

Räsänen, K., \& Vaheri, A. (2010). Proliferation and motility of HaCaT keratinocyte derivatives is enhanced by fibroblast nemosis. Experimental Cell Research, 316(10), 1739-1747. https://doi.org/10.1016/j.yexcr.2010.01.020

Rousselle, P., Braye, F., \& Dayan, G. (2018). Re-epithelialization of adult skin wounds : Cellular mechanisms and therapeutic strategies. Advanced Drug Delivery Reviews, 146, 344-365. https://doi.org/10.1016/j.addr.2018.06.019

Sampaio, T. P. D., Cartaxo-Furtado, N. A., Medeiros, A. C., Alves, H. S., Rosalen, P. L., \& Pereira, J. V. (2017). Antimicrobial Potential of Plant Extracts and Chemical Fractions of Sideroxylon obtusifolium (Roem. \& Schult.) T.D. Penn on Oral Microorganisms. The Journal of Contemporary Dental Practice, 18(5), 392-398.

Sanwal, R., \& Chaudhary, A. K. (2011). Wound healing and antimicrobial potential of Carissa spinarum Linn . in albino mice. Journal of Ethnopharmacology, 135(3), 792-796. https://doi.org/10.1016/j.jep.2011.04.025

Tharuka, N. M. D., Bathige, S. D. N. K., Oh, M., Lee, S., Kim, M. J., Priyathilaka, T. T., \& Lee, J. (2018). Molecular characterization and expression analysis of bigbelly seahorse (Hippocampus abdominalis) interleukin-10 and analysis of its potent anti-inflammatory properties in LPS-induced murine macrophage RAW 264.7 cells. Gene, 685, 1-11. https://doi.org/10.1016/j.gene.2018.10.053

Vasconcelos, M. S., Souza, T. F. G., Figueiredo, I. S., Sousa, E. T., Sousa, F. D., Moreira, R. A., Alencar, N. M. N., Lima-Filho, J. V., \& Ramos, M. V. (2018). A phytomodulatory hydrogel with enhanced healing effects. Phytotherapy Research, 1-10. https://doi.org/10.1002/ptr.6018

Zhang, H., Chen, J., \& Cen, Y. (2018). Burn wound healing potential of a polysaccharide from Sanguisorba officinalis L. in mice. Biological Macromolcules, 112, 862-867. https://doi.org/10.1016/j.ijbiomac.2018.01.214 